Strategic partnerships of the renewable energy firms in Portugal

Isabel Salavisa

Cristina Sousa

Teresa Calapez

Dezembro de 2015

WP n.o 2015/14

DOCUMENTO DE TRABALHO

WORKING PAPER

DINAMIR'CET

CENTRO DE ESTUDOS SOBRE A MUDANCA
SOCIOECONÓMICA E O TERRITÓHIO

SOCIOECON
ISCTE-IUL 


\title{
DINAMIP'CET
}

\section{Strategic partnerships of the renewable energy firms in Portugal}

\author{
Isabel Salavisa* \\ Cristina Sousa** \\ Teresa Calapez***
}

WP n. $02015 / 14$

DOI: $10.15847 /$ dinamiacet-iul.wp.2015.14

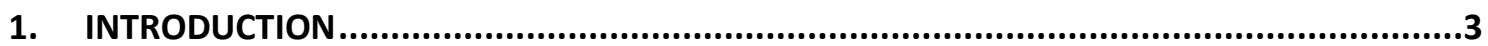

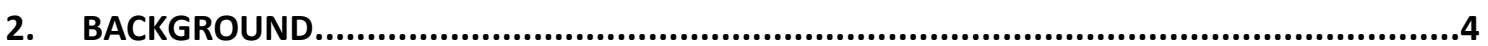

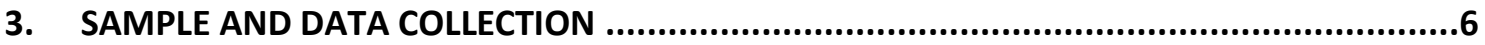

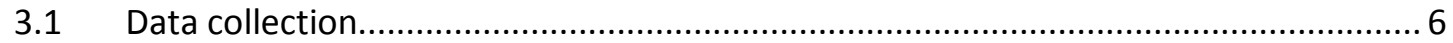

3.2 Characterization of the firms developing renewable energy technologies .................. 7

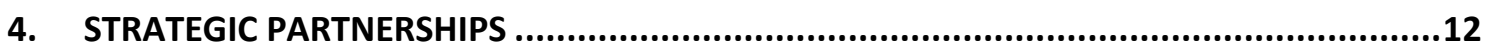

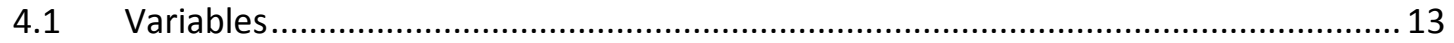

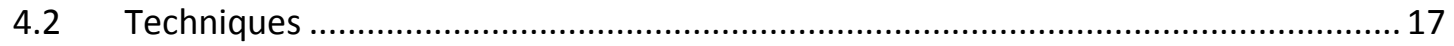

4.3 Characterization of the firms' strategic partnerships ............................................. 17

5. UNCOVERING THE FACTORS AFFECTING THE SUCCESS OF THE PARTNERSHIP ...............23

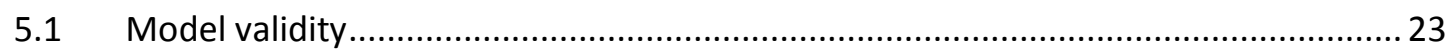

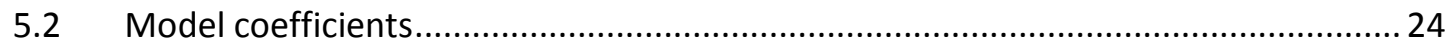

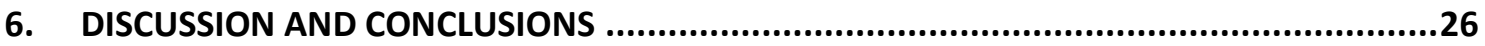

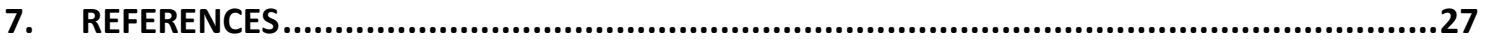

\footnotetext{
* Instituto Universitário de Lisboa (ISCTE-IUL), DINÂMIA'CET-IUL, Lisboa, Portugal.

** Instituto Universitário de Lisboa (ISCTE-IUL), DINÂMIA'CET-IUL, Lisboa, Portugal.

*** Instituto Universitário de Lisboa (ISCTE-IUL), BRU - IUL, Lisboa, Portugal.
} 


\title{
Strategic partnerships of the renewable energy firms in
}

Portugal $^{\mathrm{a}}$

\begin{abstract}
This paper focuses on the strategic partnerships established by firms operating in the renewable energy technologies sector in Portugal. The analysis aims at contributing to deepen the knowledge about the types and forms of partnerships in the renewables sector. The goal is to uncover the factors which explain the success of these partnerships and draw conclusions on the way they contributed to building a renewables cluster in Portugal.
\end{abstract}

KEYWORDS: strategic partnerships, sustainable energy technologies, renewable energy firms.

\footnotetext{
a This paper draws on research carried out within Project TESS - Transition to an environmentally sustainable energy system - The role of technology-intensive firms in the commercialization of emerging energy technologies, funded by FCT - Fundação para a Ciência e a Tecnologia (PTDC/CSECS/113568/2009), DINÂMIA'CET-IUL, Lisbon, Portugal.
} 


\section{INTRODUCTION}

This paper focuses on the strategic partnerships established by firms operating in the renewable energy technologies sector in Portugal, first and foremost young and small firms. Strategic partnerships have become frequent in knowledge-intensive sectors, which deal with the creation of complex knowledge and risky and costly investments. They are of utmost importance for young and small firms, which generally do not have in-house the full array of resources necessary for the deployment and commercialization of new technologies. The paper aims to charactherize these partnerships and to unveil the factors underlying their success. The research draws on primary data collected through detailed interviews with the founders or CEOs of 60 Portuguese renewable energy technologies firms, which encompass the vast majority of the firms operating in the sector in Portugal. These companies have identified and described a set of 174 strategic partnerships, which are the base of our empirical work.

In a first step, we conducted a descriptive analysis aiming at characterizing the strategic choices made by the firms regarding both innovation and competitive positioning, and the partnerships themselves in features such as:

- the partnership motivation;

- the partners' type: other firms, university, government, civil society associations;

- the type of interaction, formal versus informal;

- the duration of the partnership;

- the degree of trust among the partners;

- the degree of dependence between the partners;

- the degree of achievement of the partnership.

In a second step, we conducted an econometric analysis to identify the factors affecting the success of the partnerships. The dependent variable is the degree of achievement of the partnership goal, as assessed by the interviewed firms (in a Likert 7-point scale). The independent variables comprise the objectives and the kind of partnership built as well the main features of the firm like size, technological area, main type of activity and the innovation strategy. 


\section{BACKGROUND}

Particularly in high-technology sectors, networks have become a privileged instrument of companies do deploy their activity. Through networks they access a wide range of resources, they carry out collaborative $R \& D$ as well as production and commercial activities, they share risk and huge investments, and they get credibilization and counselling. Networks are of utmost importance to small firms which are unable to have in-house the various resources necessary for their activities. But even large firms are engaged in networking, in a world of increased specialization and distributed knowledge. A specific case of networks are strategic partnerships or alliances which are lasting relationships deemed as crucial by the partners (or one of them) involved.

A strategic technology partnership is a special kind of relationship since it affects the long term goals of the companies (Gilsing, Lemmens and Duysters, 2007). It is defined as "the establishment of cooperative agreements aimed at joint innovative efforts or technology transfer that can have a lasting effect on the product-market positioning of the participating companies" (Hagedoorn and Schakenraad, 1994:291). They have grown at an unprecedented scale over the last decades, due to a combination of elements including increasing complexity and uncertainty of the innovation process, technological turbulence, necessity of rapid time-to market strategy and need to resort to a wide array of technological knowledge domains (Hagedoorn and Schakenraad, 1994; and Gilsing, Lemmens and Duysters, 2007). Firms intentionally build and manage these partnerships to access resources (e.g. knowledge, complementary assets, and financial resources). In this process they establish each partnership's goal, choose the most appropriate partners and the channels of interaction, develop trust and assess the results of the partnership.

The strategic partnerships are established between young firms which are developing new generation energy technologies (Brown, Hendry and Harborne, 2007) within specific niches (Kemp, Schot and Hoogma, 1998; Bergek et al, 2008; Hekkert and Negro, 2009); between these firms and the 'old' incumbent companies (Grin, Rotmans and Schot, 2011); and finally between these firms and a diversity of organisations such as universities and public laboratories, government agencies, venture capital companies, private equities, industry associations, civil society associations, etc., both national and international. Through the networks, where tangible and intangible resources circulate, the new technological developments may flow from the innovators to the "commercializers" and users of the new technologies. 
The performance of these partnerships (or alliances) has been addressed by a large number of studies (Hagedoorn and Schakenraad, 1994; Lavie, 2007; Antoncic and Pordan, 2008). These studies take into account a diversity of features influencing the outcome, related to the context, the firms' characteristics and the structure and workings of the partnership or alliance. Hagedoorn and Schakenraad explore this subject by taking into account several contextual aspects (sector and nation specific circumstances) as well as the structure of the focal company (size and technological intensity) and the characteristics of the partnership.

The evaluation of success may become another complex issue, as Lavie (2007) as shown. This means that measuring the performance related to partnering is far from straightforward. This is quite well illustrated by a study dealing with alliances between firms and universities (Perkman, Neely and Walsh, 2011). The expected results have a multiform nature and arise at several stages of the cooperation. Therefore, they are not reducible to a single dimension. To cope with this issue, two different approaches are possible: one consists of taking into account and combining several criteria of performance; the other consists of asking the participants for an evaluation, which of course implies a direct inquiry.

The structure and composition of the partnerships should be considered. This means that we should include in the analysis aspects such as: the main objectives of the partnerships; the type of partner (company, research institution, other); the kind of relationship established (formal versus informal); the intensity of the relations deployed (proxied by the frequency of interaction and by the dependence of the focal company on its partner); and the trust deployed within the partnership. Together with the structural elements of the focal firm (size, age, technological sector, and main activity) and its strategies regarding innovation and market approach (competition through differentiation by innovation, quality, design / project versus price) the referred aspects may constitute relevant factors to explain the performance of the strategic partnership performance. Finding out the contribution of each feature to performance is the main objective of this paper. 


\section{SAMPLE AND DATA COLLECTION}

This section provides the characterization of the interviewed companies and the data collection procedures adopted.

The research draws on primary data collected through detailed interviews with the founders or CEOs of 60 Portuguese renewable energy technologies firms, which encompass the vast majority of the firms developing technologies in the sector in Portugal. These companies have identified and described a set of 174 strategic partnerships, which are the base of the empirical work.

\subsection{Data collection}

To the best of our knowledge, there is no database on the Portuguese renewable energy firms. Therefore, we have made an extensive search to identify all companies operating in the field. A gradual process has permitted the identification of these companies. To begin with, we consulted the lists of members of the industry associations, namely APREN (Portuguese Association of Renewable Energies) and APISOLAR (Portuguese Association of Solar Energy). At the same time, a detailed search for information was carried out in the business press. Then, once the interviews began, a snowball technique was systematically used, by asking the interviews to identify to the best of their knowledge the companies operating in the market. This effort enabled the construction of a database with 484 companies operating in the renewable energy sector, with some basic characterization of the company (when available): name, address, year of start-up, size and main activity (NACE code).

This research focuses on the companies that develop renewable energy technologies. This means that it only considers the sub-set of companies that are making an effort to develop new technologies/products/services, therefore excluding the ones that only commercialize or install technologies/products developed by third parties. In order to select the companies to be included in the sample, we have conducted a detailed analysis of each firm website. We have also resorted to on-line databases related to innovation activities, such as patenting (ESPACENET), collaborative R\&D projects (CORDIS for European projects and AdI database for Portuguese projects) and Portuguese university spin-offs lists. This process enabled the identification of 84 firms, which were contacted by phone and e-mail in order to participate in this study. From the identified set we have interviewed 60 firms, which constitute our sample.

Data was collected through detailed interviews with the companies' founders or CEOs. These interviews were conducted between April 2013 and July 2014. They had an average 
length of 1.5 hours and were supported by a semi-structured questionnaire. The interviewees were asked to provide a brief history of the firm creation and then to give detailed information on the companies' activities and strategies, with emphasis on the processes of development and commercialization of technologies, products or services. The interviewees were also asked to identify the most relevant strategic partnerships of the company (up to five) and to provide information on each partnership, namely:

- the partnership motivation;

- the partners' type (other firms, university, government, civil society associations);

- the type of interaction (formal, informal);

- the frequency of interaction;

- the duration of the partnership;

- the degree of trust in the partner;

- the degree of dependence on the partner;

- the degree of achievement of the partnership.

Data collected through the interviews was complemented with an extensive search for documentary information on the firms, namely in the firms' web pages and corporate reports and in the business press.

\subsection{Characterization of the firms developing renewable energy technologies}

The development of the Portuguese renewable energy sector is a relatively recent phenomenon, strongly supported by public policies, including feed-in-tariffs, priority of access into the grid of electricity generated from renewable sources, fiscal incentives, public financing (through public investment or grants) and public competitive bidding (REN21, 2011). These policy efforts resulted in the expansion of the production of renewable electricity and generated a favourable environment for the creation of firms developing and exploiting renewable energy technologies (Fontes, Sousa and Pimenta, 2012).

The data from our sample reflects the relative youth of the sector. Apart from a small group of companies (operating in the energy sector or in other sectors relevant for renewable energy technologies, as will be explained later), the process of firm creation started in the early 2000's and only took off after 2005 (Figure 1). 
Figure 1 - Year of firm creation

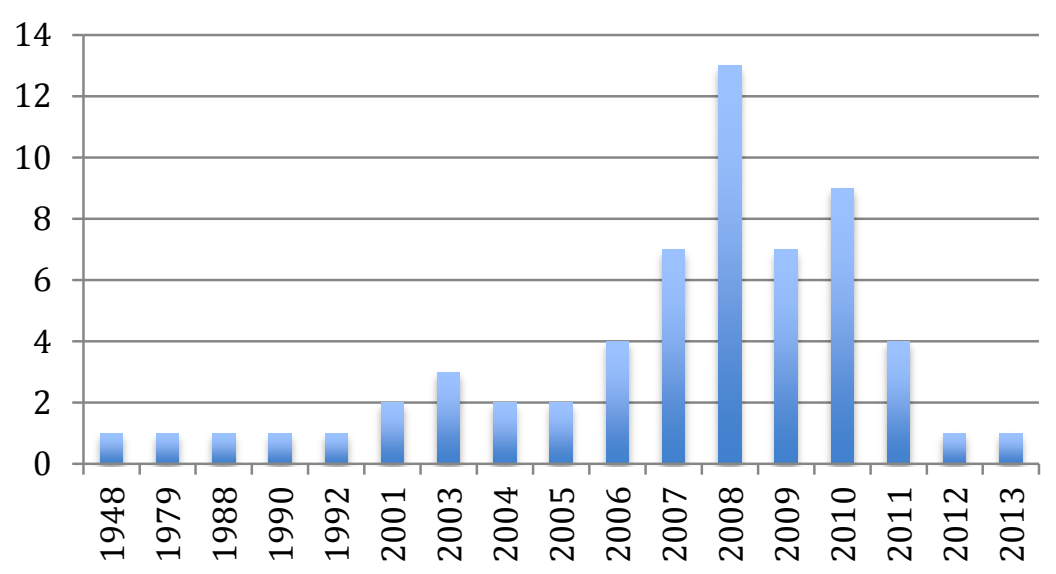

In terms of technological area (Figure 2), most of the companies (85\%) are developing technologies to one or more renewable energy sources (RES), with emphasis on solar (40\%) and wind (23\%). The remaining $15 \%$ are dedicated to systems engineering in the area of renewable energy technologies (RET).

Figure 2 - Technological area

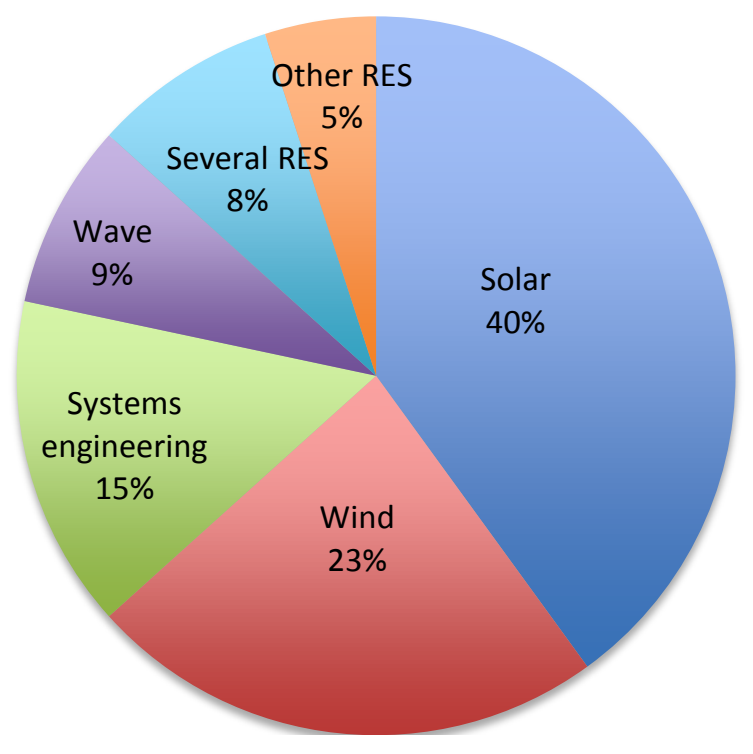

The analysis of the company's main activity (Figure 3) reveals that they are mainly focused on the commercialization of innovative services (38\%) and on the development/ commercialization of own products or technologies (35\%). 
Figure 3 - Main activity of the firm

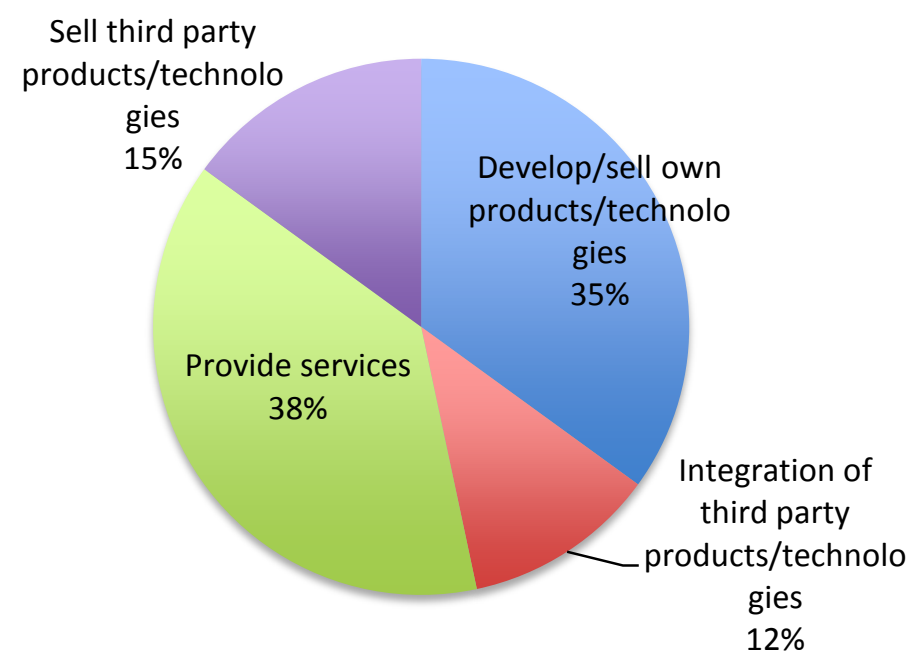

The studied companies have different origins (Figure 4). About 1/3 are academic spin-offs, formed to commercially exploit knowledge produced in Portuguese universities. Another relevant group consists of corporate spin-offs. Most spin-offs, both academic and corporate, were created after 2005 and are operating in solar or wind technological areas (Table 1). Academic spin-offs are also operating in wave technologies. The third group of companies is made of independent companies while the fourth includes subsidiaries of multinational corporations, joint ventures and business units of large Portuguese groups operating in the field of energy technologies.

Figure 4 - Origin of the firm

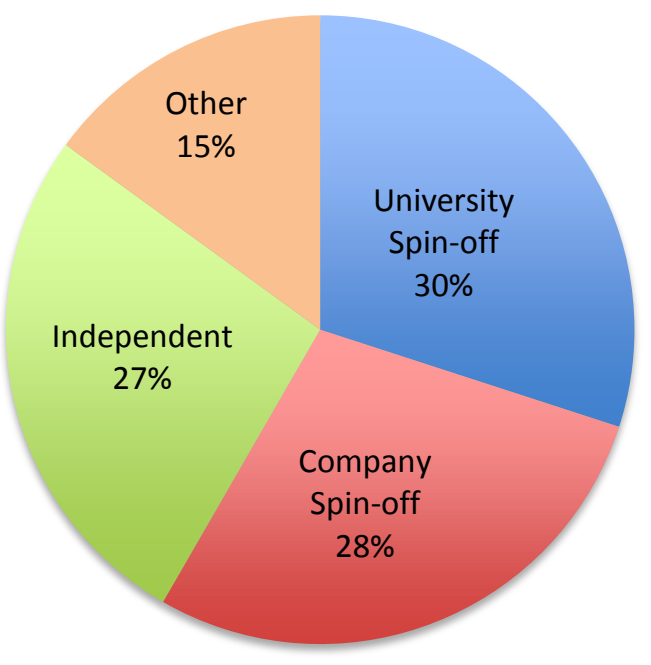


Strategic partnerships of the renewable energy firms in Portugal

Table 1 - Start-up year and technological area of academic and corporate spin-offs (\%)

\begin{tabular}{llcc}
\hline & & Academic spin-offs & Corporate spin-offs \\
\hline Start-up year & Up to 2000 & $11 \%$ & - \\
& $2001-2004$ & $17 \%$ & $6 \%$ \\
& $2005-2008$ & $33 \%$ & $53 \%$ \\
\multirow{2}{*}{ Technological area } & After 2008 & $39 \%$ & $41 \%$ \\
& Solar & $28 \%$ & $41 \%$ \\
& Wind & $22 \%$ & $29 \%$ \\
& Systems engineering & $17 \%$ & $18 \%$ \\
& Wave & $22 \%$ & - \\
& Other RES & $11 \%$ & - \\
& Several RES & - & $12 \%$ \\
\hline
\end{tabular}

Micro and small companies predominate in our sample (Figure 5). They are mostly operating in the solar technological area, but we can find them in all technological areas (Figure 6). Large companies are related to Portuguese industrial groups, often operating in the conventional energy area. They cover several RES or are focused on solar or wind technologies.

Figure 5 - Firm size, in 2012

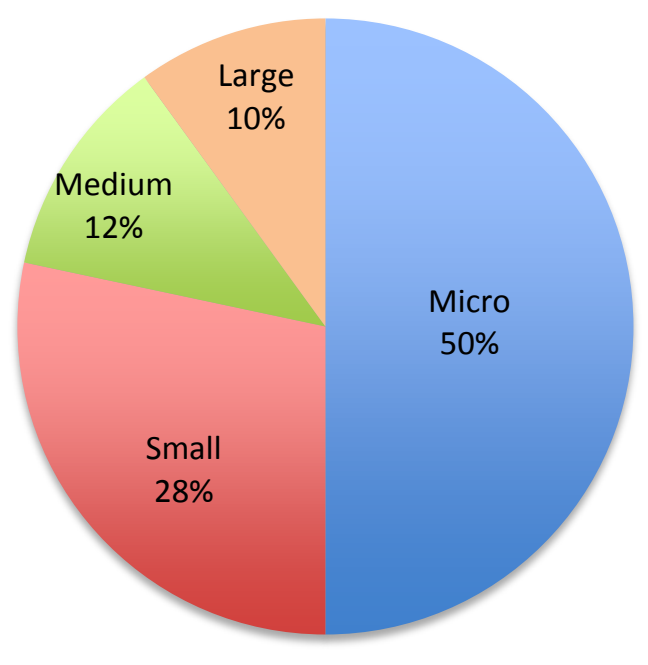


Figure 6 - Firm size and technological area (number of companies)

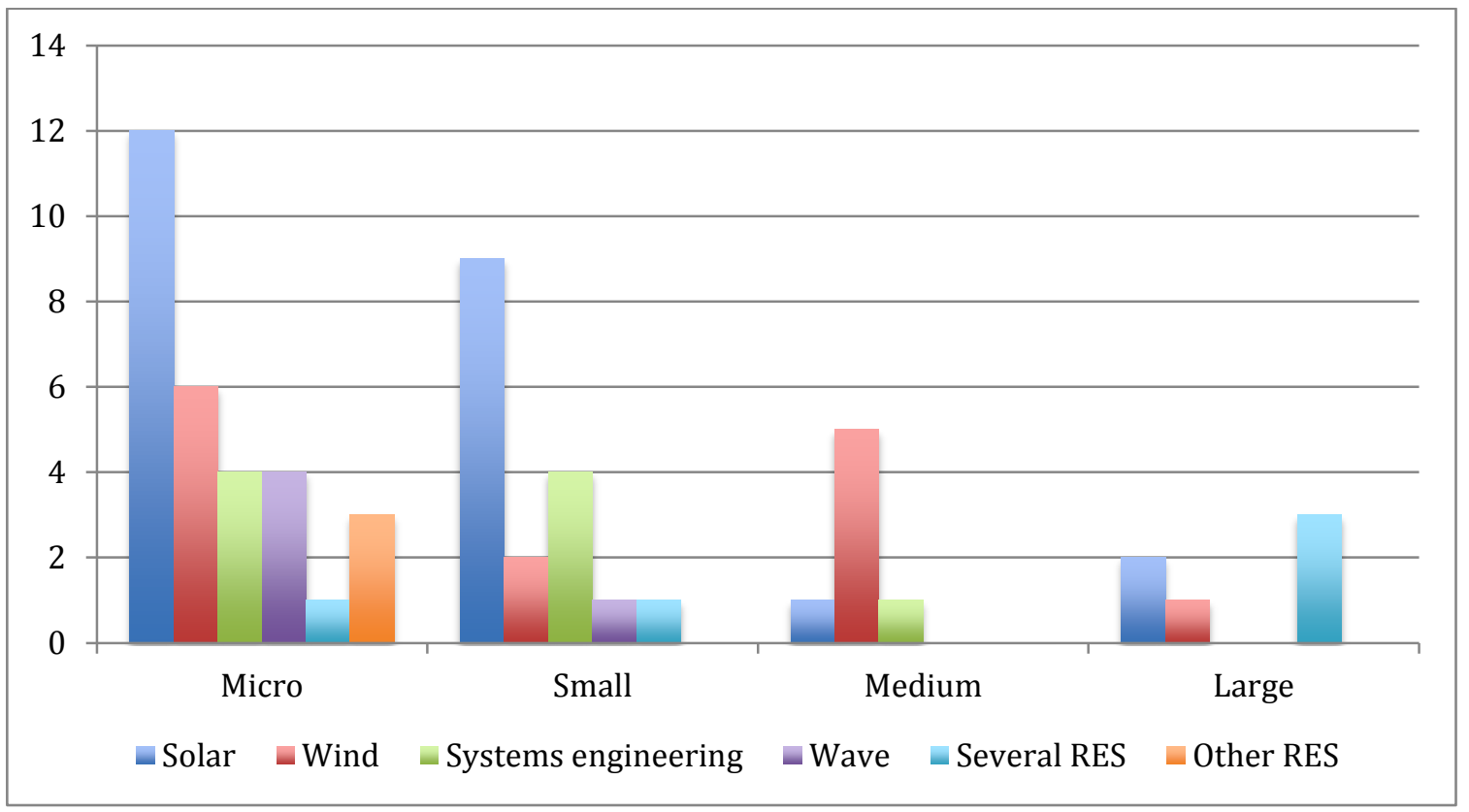

These companies base their competitive positioning on differentiation (Figure 7). In fact, only one of the interviewed companies considers that pricing is its most relevant strategic advantage. Differentiation is mainly archived through quality (47\%) or through technological innovation $(33 \%)$.

\section{Figure 7 - Competitive positioning}

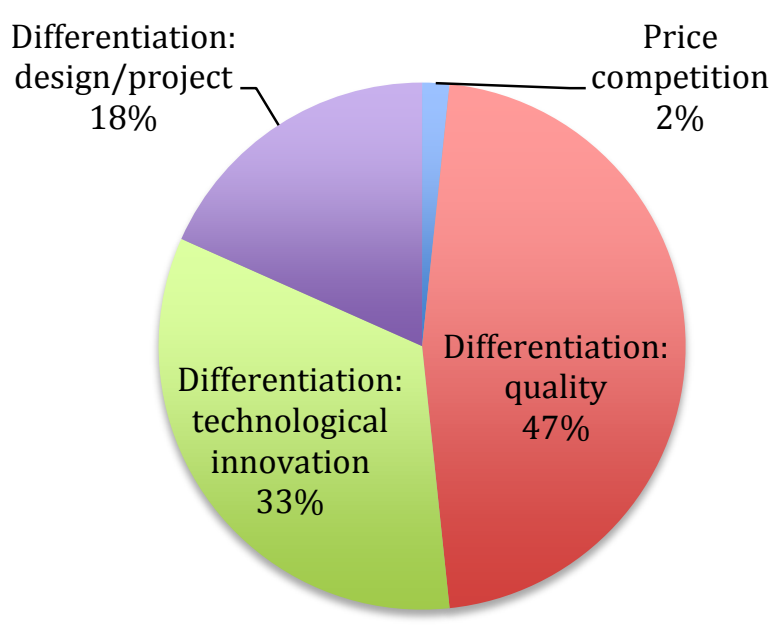


Regarding the innovation strategy, interviewees were asked to assess the importance of several innovation practices, using a 7 point Likert-type scale varying from $1=$ unimportant to $7=$ very important. Three innovation strategies were considered: i) developing products/ services/ technologies that are new to the market; ii) developing products/ services/ technologies that are new to the firm; iii) improving existing products/ services/ technologies. Figure 8 shows that innovation is generally perceived as important by the companies operating in renewable technologies, in line with the novelty of the sector and its technologies. It is noteworthy to stress that the companies consider new to the market innovations (therefore more radical) more important than new to the firm innovations or improvements of existing products/ services/ technologies (Figure 8).

The specific innovation strategy of each firm is likely to affect the characteristics of the partnerships established and their outcomes. More disruptive strategies are usually associated with higher uncertainty and draw frequently on the deployment of advanced technologies, requiring the contribution of research institutions.

Figure 8 - Innovation strategy

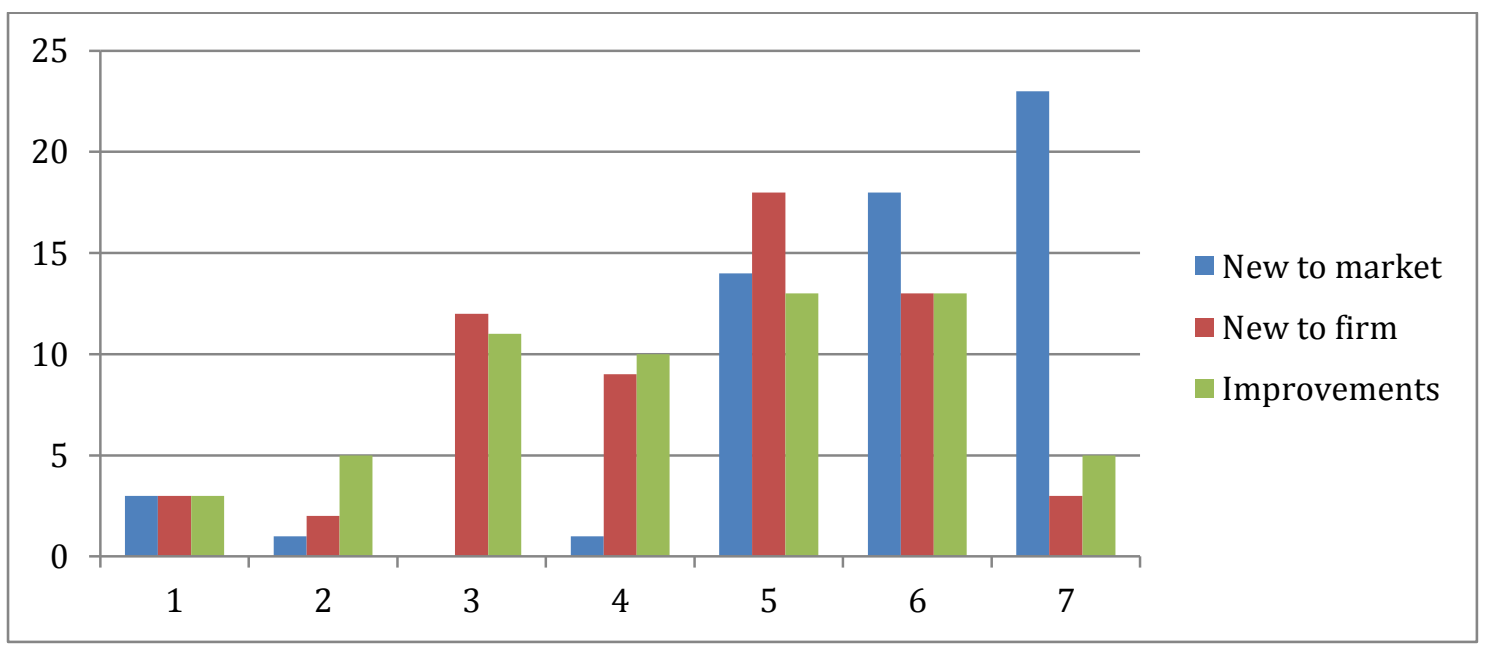

\section{STRATEGIC PARTNERSHIPS}

The empirical analysis focus on the strategic partnerships of the firms presented above. It is divided in two steps that involve different methodological options. In a first step, we conducted an analysis aiming at uncovering the characteristics of the strategic choices made by firms regarding their partnerships. In a second step, we conducted an econometric analysis to identify the factors affecting the success of these partnerships. 
The empirical strategy involved the preliminary choice of the variables and of the techniques to be used. The rationale behind the choice of the variables is presented in section 2. In sections 4.2 we present the techniques used in the analysis of the partnerships and in section 6 the identification of the factors affecting their success, respectively.

\subsection{Variables}

In order to characterize both the partnerships and their success and the strategic choices made by the companies, a set of variables was selected (Table 2). The selection of the variables was supported by the literature review. These variables are further used as explanatory factors of the perceived degree of success of the partnerships.

In the field of new technologies development, strategic partnerships can be defined as "cooperative agreements for reciprocal technology sharing and joint undertaking of research between independent actors that keep their own corporate identity during the collaboration" (Gilsing, Lemmens and Duysters, 2007: 227).

The choices made to build these strategic partnerships should be aligned with the company's competitive positioning and mobilize the company's relational capability' (Dyer and Singh, 1998).

Strategic partnerships can have different motivations (Moensted, 2007; Mohr and Spekman, 1994), which may influence the process of partnership building (e.g. in terms of partner selection). For instance, if the purpose of the partnership is to access a resource, the firm has to identify and select potential providers of that resource. For this reason, we have asked the company to identify the main motivation(s) behind each strategic partnership and considered the partnership motivations in the analysis.

One of the central aspects of a partnership is the choice of the partner. Different types of partner can provide different resources (Baum, Calabrese and Silverman, 2000; Salavisa, Sousa and Fontes, 2012) and raise different challenges in terms of partnership management, namely in terms of organizational proximity (Broekel and Boschma, 2012). To cover this aspect, we have classified all partners into one of the following categories: companies, Science \& Technology Institutions (includes universities, research centers and public research organizations) and other organizations (includes government agencies, financial companies, industry and trade associations and civil society organizations). This corresponds to the variable "type of partner". 
Inter-organizational relationships may encompass a dense web of ties, both formal and informal. Formal relations involve some type of contract, while informal relations are associated with personal ties between members of different organizations. According to Powell and Grodal (2005), subcontracting relationships, strategic alliances and the participation in research consortia are examples of formal (contractual) relations. Previous research describes informal relations as being associated with individual trajectories and previous interactions and depending strongly on loyalty and reciprocity (Dahl and Pedersen, 2004; Kachra and White, 2008). Formal and informal relations can be strongly intertwined: informal relations can trigger formal agreements (Powell et al, 1996), and can have an important contribution to their success (Kreiner and Schultz, 1993). Scholars also suggest that relationships will tend to be formalized when lower levels of trust are present. In order to capture this debate, our research considers the variable "type of interaction", distinguishing between formal (contractualized) relations and those that have been kept informal.

Research on networks and on strategic alliances also considers the role of the frequency of the interaction between the actors, considering it as a proxy to the intensity of the relation. This follows the seminal work of Granovetter $(1973,1982)$, who distinguishes between weak and strong ties. According to this author, in the context of personal relations, the strength of the tie depends on a combination of factors, namely the amount of time, emotional intensity, intimacy and reciprocity that characterize the relation. In the case of inter-organizational relations, the intensity of the tie can be described as a combination of two factors: the amount of resources exchanged and the frequency of contact between the partners (Zhao and Aram, 1995). Following this idea, we consider the frequency of the interaction between the partners in our research. 
Strategic partnerships of the renewable energy firms in Portugal

Table 2 - Variables definition

\begin{tabular}{|c|c|c|c|}
\hline Variable & Question & Type & Categories \\
\hline Motivation & $\begin{array}{l}\text { What was the motivation for starting/entering the } \\
\text { partnership }\end{array}$ & $\begin{array}{l}\text { Multiple choice (Yes/No } \\
\text { for each motivation) }\end{array}$ & $\begin{array}{l}\text { M1: Access to information } \\
\text { M2: Access to knowledge } \\
\text { M3: Joint development of knowledge/ technologies/ products } \\
\text { M4: Access to markets } \\
\text { M5: Funding } \\
\text { M6: Access to other resource } \\
\text { M7: Credibilization/legitimacy }\end{array}$ \\
\hline Type of partner & Name and type of partner & Nominal & $\begin{array}{l}\text { 1: Company } \\
\text { 2: Science \& Technology Institution } \\
\text { 3: Other }\end{array}$ \\
\hline Type of interaction & Is the relation formal or informal? & Nominal & $\begin{array}{l}\text { 1: Formal } \\
\text { 2: Informal }\end{array}$ \\
\hline Interaction frequency & How frequent is the interaction with the partner? & Ordinal & $\begin{array}{l}\text { 4: Daily; 3: Weekly (one or several times per week, not daily); 2: } \\
\text { Monthly (one or several times per month, not weekly); } 1 \text { : } \\
\text { Occasionally (less than one time per month) }\end{array}$ \\
\hline Duration of the partnership & $\begin{array}{l}\text { In which year did this partnership begin? } \\
\text { Duration }=2014-\text { initial year }\end{array}$ & Metric & Number of years \\
\hline Degree of trust & Which is the degree of trust in the partner? & Ordinal & Likert-type item, from 1: absence of trust to 7 : total trust \\
\hline Degree of dependence & Which is the degree of dependence on the partner? & Ordinal & $\begin{array}{l}\text { Likert-type item, from 1: absence of dependence to } 7 \text { : total } \\
\text { dependence }\end{array}$ \\
\hline Degree of achievement & $\begin{array}{l}\text { How do you assess the partnership in terms of its } \\
\text { goals achievement? }\end{array}$ & Ordinal & $\begin{array}{l}\text { Likert-type item, from 1: Very low achievement to } 7 \text { : Very high } \\
\text { achievement }\end{array}$ \\
\hline
\end{tabular}


The intensity of the relation is also related to trust. Trust can be defined as "the belief that a party's word is reliable and that a party will fulfill its obligation in an exchange" (Mohr and Spekman, 1994: 138). Trust plays an important role in inter-organizational relations. It increases the will of people to share their knowledge (Politis, 2003) and contributes for success of knowledge-based (Ford, 2004), market-based (Aulakh, Kotabe and Sahay, 1996; Mohr and Spekman, 1994) and legitimacy-based (Shane and Stuart, 2002) partnerships. Despite this positive effect of trust, previous literature also acknowledges that the existence of trust does not deter the use of other control mechanisms (Moensted, 2007), namely contractual (Fontes and Sousa, 2015). Trust can be built, based on evaluation mechanisms of the partner and on past interaction experience (Gulati, 1995), namely when one organization continuously shares information and knowledge with another one (Wang and Rubenstein-Montano, 2003). It builds upon credibility and successful previous relations. Additionally, trust becomes easier among organizations (and individuals) that share similar characteristics (McPherson, Smith-Lovin and Cook, 2001; Moensted, 2007). To capture the trust dimension, the interview schedule includes a question on the degree of trust on the partner and our analysis incorporates the variable "Degree of trust".

Previous research also stress that dependence on the partner can influence the success of the partnership (Mohr and Spekman, 1994). Authors tend to stress two different aspects: interdependency and power asymmetry between partners. Interdependency is linked to the existence of complementarities between the organizations. This idea follows Teece's concept of complementary assets and the need to form partnership to access them (Teece, 1986). Partnerships to access complementary assets can be advantageous both for incumbents and for new entrants (Rothaermel, 2001; Stuart, Ozdemir and Ding, 2007). But scholars also acknowledge the risk of power asymmetry between partners, namely in partnerships between incumbents and small entrants in new technology areas. In this case, incumbents can use their power to capture a large share of the partnership benefits, preventing the growth of the small entrants (Audretsch and Feldman, 2003). Given the power asymmetry between partners, strong contractual relationships may be designed in order to protect the new firms from the partners' potentially opportunistic behaviour (Lerner and Merges, 1998; Teece, 1986). In order to capture the dependence, the interview schedule included a question on the degree of dependence on each strategic partner and the variable "Degree of dependence" is included in our analysis.

Since our ultimate goal is to develop a model to explain the success of the partnerships built by the companies that develop renewable energy technologies, we need to clarify the meaning of success in this context. As stressed by Mohr and Spekman (1994), success can be proxied by the partnership longevity or by its non-dissolution. However, this does not really capture the success of the relation. In fact, some very successful partnerships come to an end, while due to inertia 
mechanisms some non-successful partnerships can have a long life (Reuer, Zollo and Singh, 2002). Therefore, as suggested by Mohr and Spekman (1994) we use an "affective measure" based on the company's evaluation of the degree of achievement of the partnership initial goals.

Following this idea, in the interview schedule we explicitly asked the interviewees to assess the degree of achievement of each strategic partnership. We have used a 7-point Likert scale, where 1 means the lack of goals achievement and 7 means the total achievement of goals. As it will be shown in the results, low levels of achievement (levels 1 and 2) were seldom reported and the distribution is mostly concentrated in the "positive" part of the scale (i.e. levels 5 to 7), with a substantial number of relationships stating full achievement (level 7). This suggested recoding the original variable into three categories: low achievement of goals (grouping levels 1 to 4); high achievement of goals (grouping levels 5 and 6); and full achievement of goals (level 7). This recoding emphasizes the differences between low achievement and full achievement.

\subsection{Techniques}

In order to identify the factors affecting the success of the partnership, we conducted an econometric analysis. We have run an ordinal logistic regression, where the dependent variable is the degree of the partnership goal achievement and the independent variables reflect the firm's strategic choices. We have also considered some control variables, like firm size, technological area, main activity and innovation strategy.

The ordinal logistic regression was chosen due to the ordinal nature of the dependent variable and the mixed level nature of the independent variables. This type of regression is a generalization of the logit model, when the dependent variable is not binary, having three or more ordered categories.

\subsection{Characterization of the firms' strategic partnerships}

This section aims to characterize the strategic choices made by firms regarding their partnerships. More specifically it reveals: the strategic motivation guiding the establishment of the partnership; the partner's type; the type of interaction, that is, if the partnership is formal or informal; the frequency of the interaction; the degree of trust in the partner; and the degree of dependence on the partner.

As previously mentioned, strategic partnerships can be motivated by several reasons. In the case of the partnerships being analyzed, we find four major motivations (Figure 9): the will/need to access markets (the interviewees mention this motivation for $36 \%$ of the partnerships), the 
will/need to access knowledge (31\%), both of which point to complementary competences, the joint development of new products/services/technologies (25\%) and the access to legitimacy $(23 \%)$.

Figure 9 - The main motivation(s) of the partnership

(\% of the partnerships that mention each motivation)

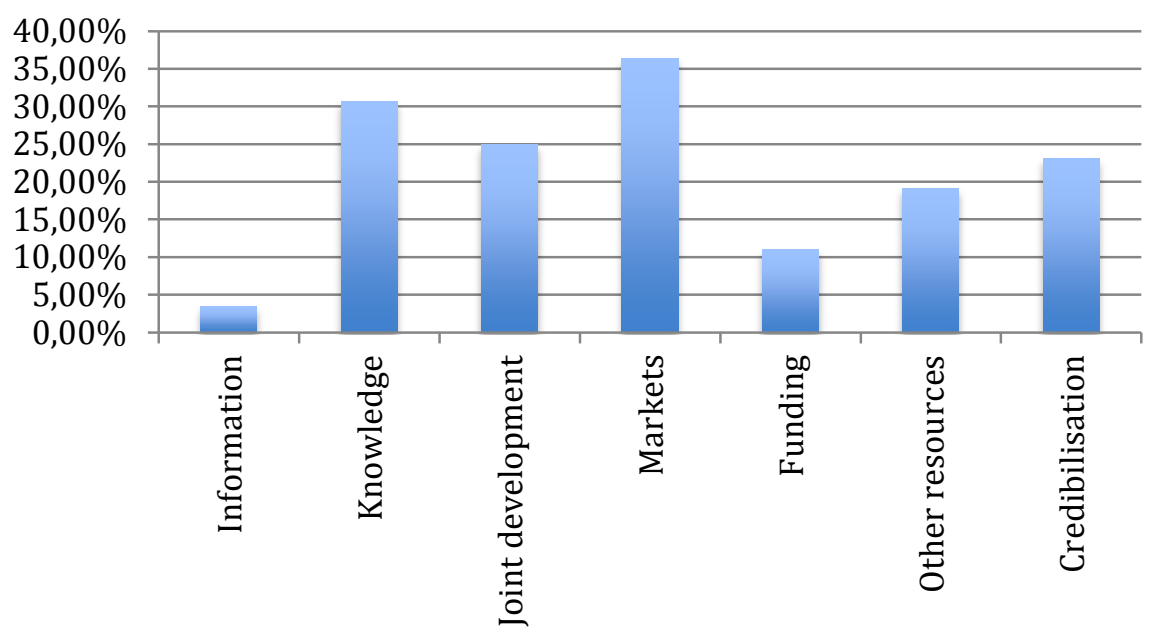

Regarding the type of partner, the results show that most partnerships are established with other companies (Figure 10), particularly to access markets and joint development of products/services/technologies (Figure 11). Not surprisingly, partnerships with STI are mostly for knowledge access.

Figure 10 - Type of partner

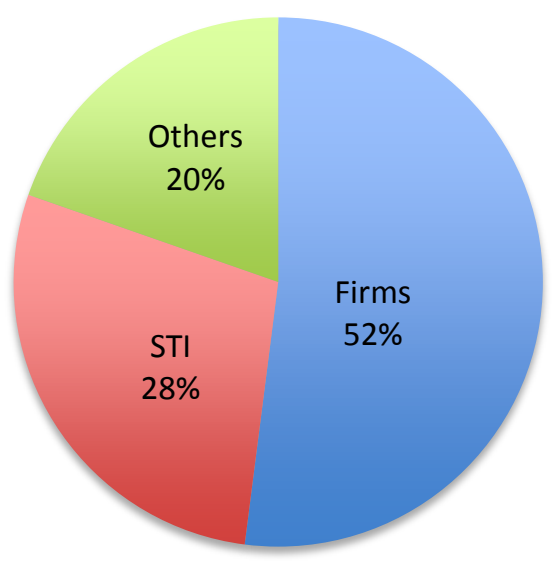


Figure 11 - Type of partner and partnership motivation (number of partnerships)

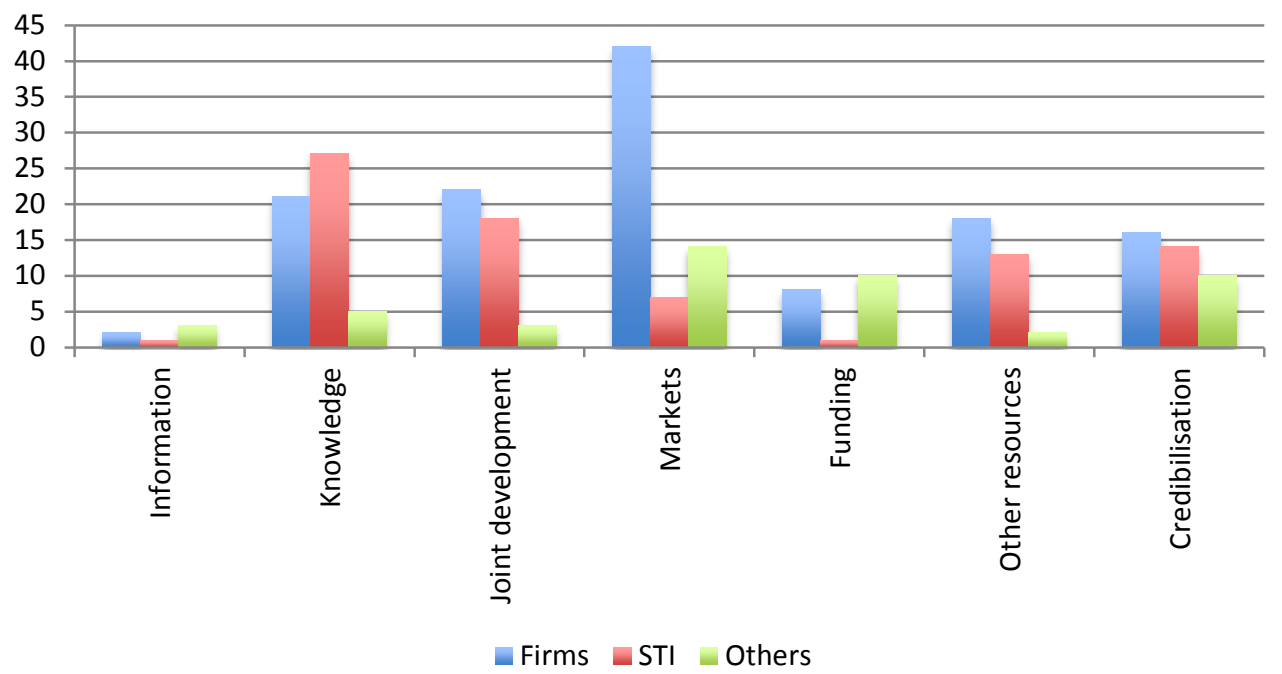

The large majority (90\%) of these partnerships is formal (Figure 12 and Table 3). Contractualization tends to be higher when the partner is a firm.

Figure 12 - Type of relation

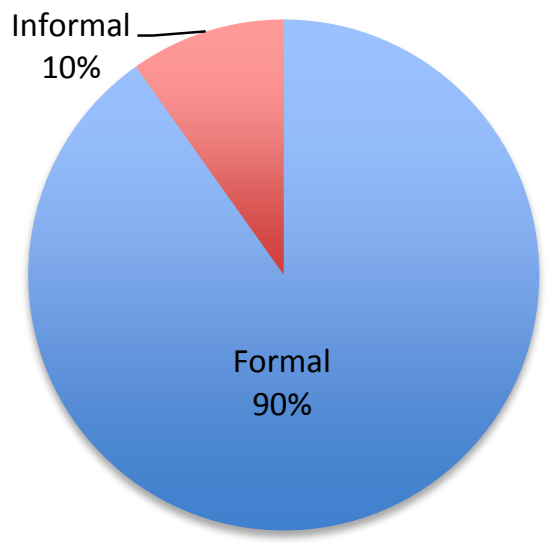

Table 3 - Type of relation and type of partner

\begin{tabular}{llrrrrr}
\hline & \multicolumn{2}{c}{ STI } & \multicolumn{2}{c}{ Others } & Firms & Total \\
\hline Relation type & Formal & Count & 40 & 30 & 87 & 157 \\
& & $\%$ & $81,6 \%$ & $88,2 \%$ & $95,6 \%$ & $90,2 \%$ \\
& \multirow{2}{*}{ Informal } & Count & 9 & 4 & 4 & 17 \\
& & $\%$ & $18,4 \%$ & $11,8 \%$ & $4,4 \%$ & $9,8 \%$ \\
\cline { 3 - 7 } Total & Count & 49 & 34 & 91 & 174 \\
& & $100,0 \%$ & $100,0 \%$ & $100,0 \%$ & $100,0 \%$ \\
\hline & & & & & & 19
\end{tabular}

DINÂMIA'CET - IUL, Centro de Estudos sobre a Mudança Socioeconómica e o Território 
The frequency of interaction, originally collected as an open question, was categorized as described in Table 2. The companies interact with their strategic partners quite frequently (Figure 13), since in $92 \%$ of the cases the interaction occurs at least once a month. Weekly contact is the most frequent situation.

Table 4 - Frequency of interaction

\begin{tabular}{llrr}
\hline & & Count & \% \\
\hline Valid & Daily & 46 & 27,2 \\
& Weekly & 59 & 34,9 \\
& Monthly & 51 & 30,2 \\
& Occasionally & 13 & 7,7 \\
& Total & 169 & 100,0 \\
Missing & NR & 5 & \\
Total & & 174 & \\
& & & \\
\hline
\end{tabular}

Figure 13 - Frequency of interaction (\% of partnerships)

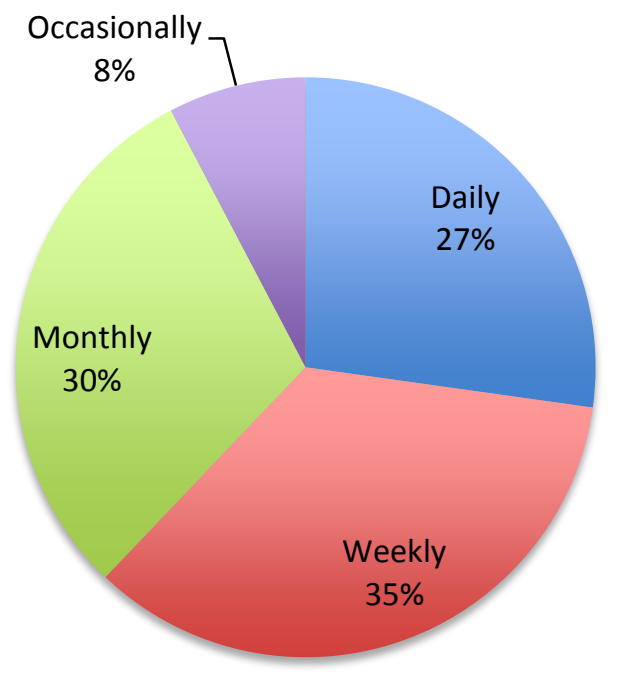

The distribution of the partnerships in terms of the degree of trust shows that these companies reveal a high level of trust in their strategic partners (Figure 14). In fact, in 3/4 of the cases we observe a total (degree of trust 7) or very high (degree of trust 6) degree of trust in the partner. 
Figure 14 - Degree of trust in the partner (number of partnerships)

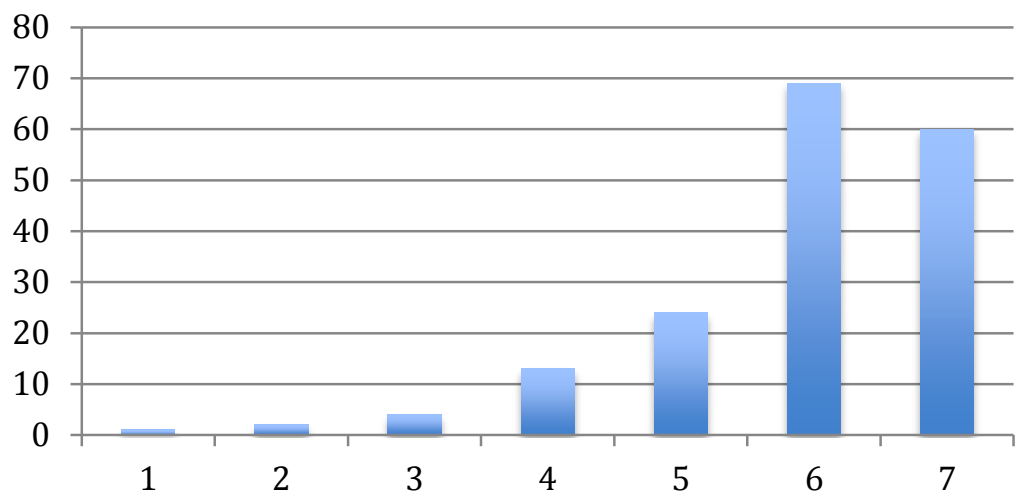

The distribution of the partnerships in terms of the degree of dependence is much less skewed (Figure 15). We can observe that only in a small number of cases (7\%) the companies consider to be totally dependent on the partner. However, high and very high degrees of dependence are quite frequent.

Figure 15 - Degree of dependence on the partner (number of partnerships)

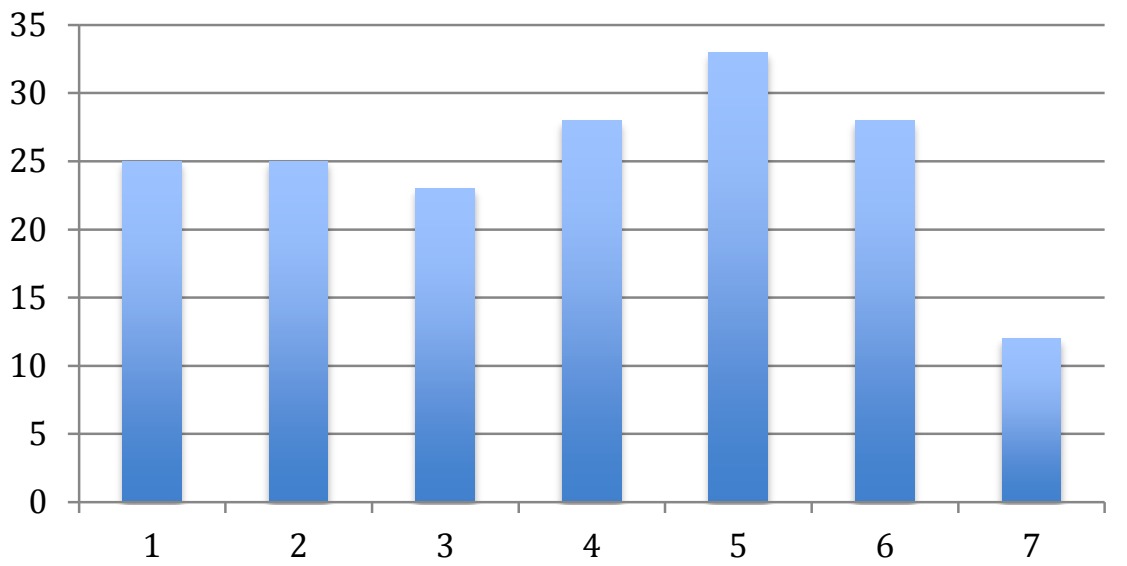

The degree of trust and the degree of dependence (Figures 13 and 14), though being Likert-type items, were treated as metric variables in what the econometric model was concerned. This was mainly due to the fact that the ordinal regression model used does not allow independent variables to be of the ordinal type, only nominal or metric. The average dependency level is 3.9 ( $\mathrm{s}=1.86$ ) and the average trust level is $5.9(\mathrm{~s}=1.15)$. 
Regarding the duration of the partnership (Figure 16) the average is 5.5 years, denoting some stability in these strategic relations. In fact, about $10 \%$ of the partnerships are in place for 10 or more years, obviously for the case of older companies. But it is also visible a rejuvenation of these partnerships, associated both with young companies and the search for new partners by incumbents.

Figure 16 - Duration of the partnership (years)

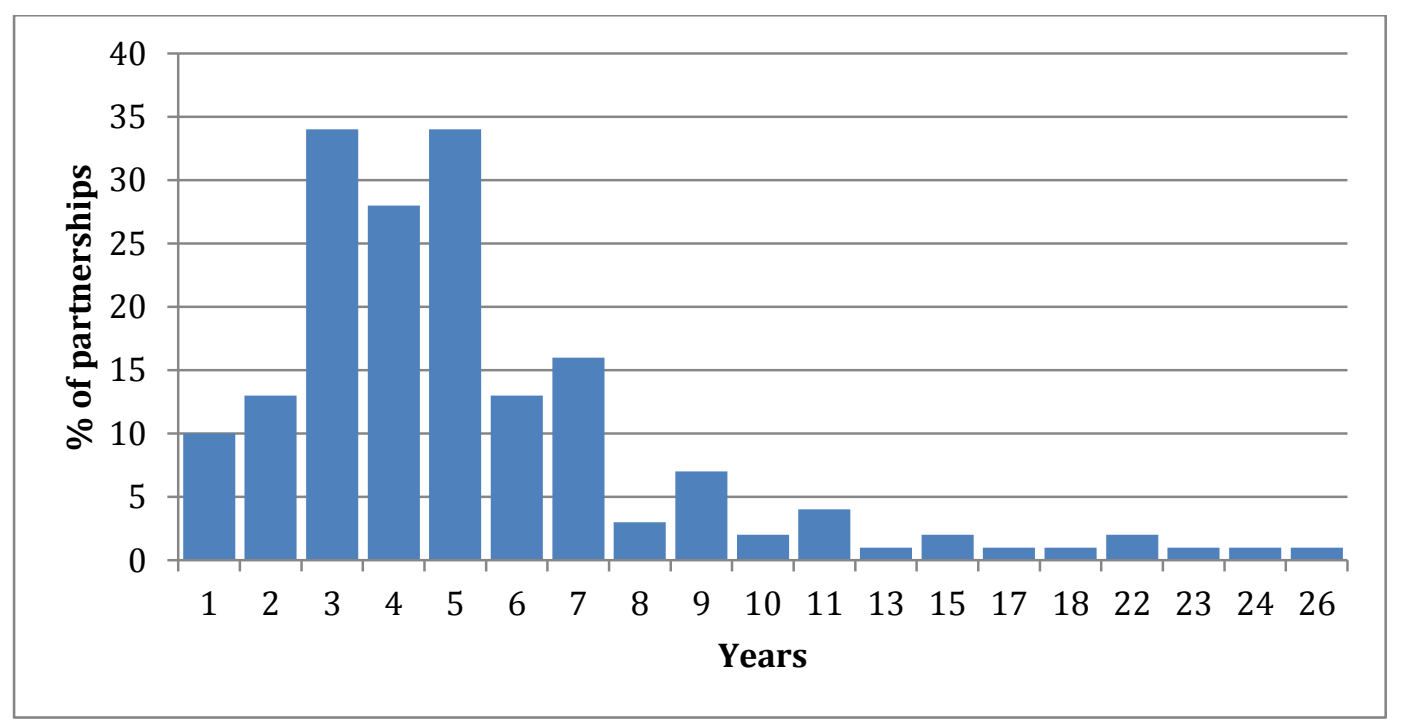

As mentioned before, the distribution of the degree of achievement is skewed towards the high values of the scale (Figure 17), reflecting a positive assessment of the partnerships in terms of their initial goals attainment. In more than $1 / 3$ of the cases, the companies consider that the partnership has a very high degree of achievement (degree 6) and in $1 / 4$ of the cases they report full achievement of the initial goals (degree 7).

Figure 17 - Degree of achievement (number of partnerships)

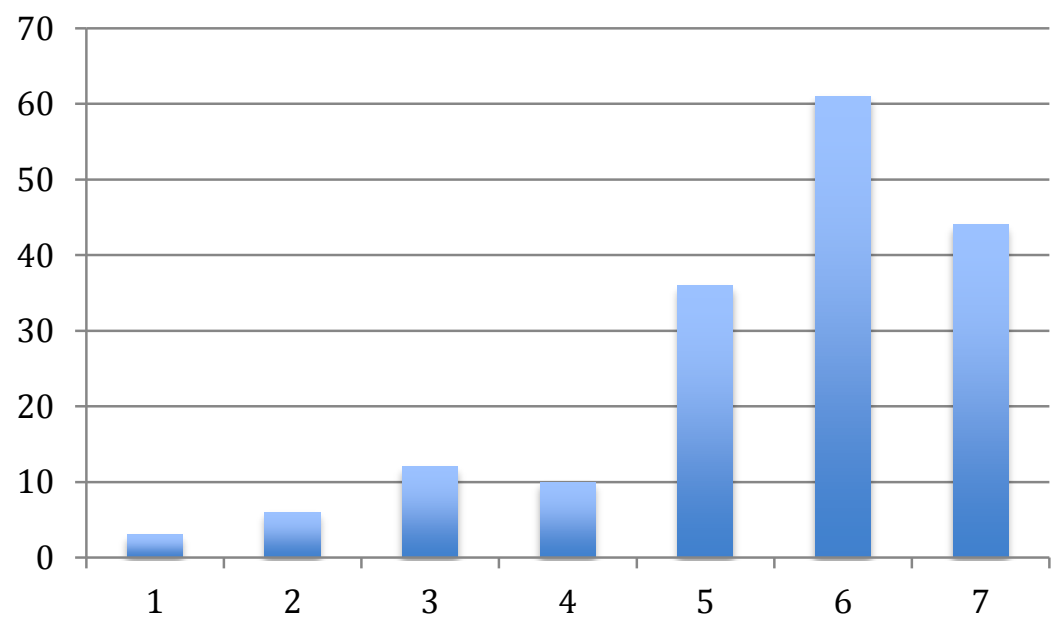

DINÂMIA'CET - IUL, Centro de Estudos sobre a Mudança Socioeconómica e o Território 
In terms of our proposed econometric model, the degree of achievement was recoded into three categories: low (levels 1 to 4), high (levels 5 and 6) and full (level 7) achievement of goals (Figure $18)$.

Figure 18 - Degree of achievement (recoded)

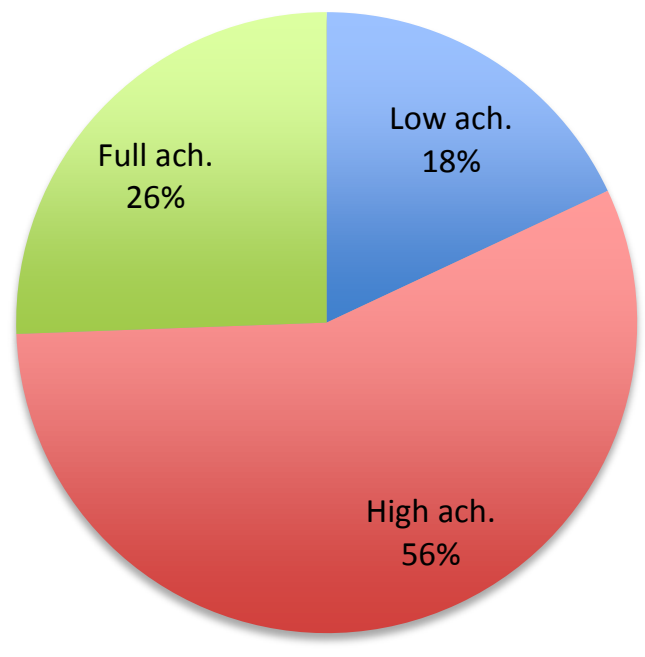

\section{UNCOVERING THE FACTORS AFFECTING THE SUCCESS OF THE PARTNERSHIP}

\subsection{Model validity}

The estimation has drawn on a broad set of independent variables, which has progressively been reduced in order to avoid overfitting issues. For this reason, potentially interesting variables such as credibilization (one of the features of motivation to establishing a partnership) have been dropped out, since they revealed as not significant in the early estimations of the model.

As already referred to, we used an ordinal logistic model with the 3 category levels of achievement as the independent variable. The model fits data reasonably well (-2 Log Likelihood $=255.2$, Chi-square $(24)=65.9$, p-value $<0.001$ ), revealing a pseudo-R2 (Nagelkerke) of 0.38. The goodness-of-fit measures (Pearson chi-square $(286 \mathrm{df})=349.2 ; \mathrm{p}$-value $<0.05$; Deviance chi-square $(286 \mathrm{df})=252.5$, p-value $>0.9)$ are not reliable, because we have several metric predictors (trust, dependency, duration of relationship and the three innovation variables) as well as some more categorical ones (Nosuris, 2012). 
The parallel lines assumption, i.e. the guarantee that the effect of each predictor is the same for the different logit functions is met $(-2 \log$ Likelihood $=220.4$, Chi-square $(24)=34.8$, p-value $>0.05)$.

\subsection{Model coefficients}

Trust in the partner and dependence on the partner revealed a significant positive impact on the achievement of goals: the odds of indicating a higher level of achievement increase by 1.7 (a $70 \%$ raise) for each unit increase in the trust level, while the odds of indicating a higher level of achievement increase by 1.37 (a 37\% raise) for each unit increase in the dependency level. Similarly, the odds of indicating a higher level of achievement increase by 1.12 (a 12\% raise) for each year increase in the duration of the relationship.

Another variable with a positive impact on the level of achievement of goals is the monthly frequency of interaction when compared to the reference category, which is the daily interaction: its odds of achieving higher levels of fulfillment of the objectives are more than two times higher.

On the other hand, access to knowledge as a principal motivation for entailing a partnership is associated with weaker evaluations of achievement.

Some control variables characterizing the firms were introduced in the model. It is the case of the firm's size, technological area, main activity and innovation strategy. However, the impact of these variables on the level of achievement of goals is negligible, with two exceptions: i) the 'Several RES' firms which are less prone to indicate a higher level of achievement of goals than firms who act only in the wind area, and ii) the importance given to the introduction of new products to the market, where a unit increase in this level of importance decreases by a factor of 0.73 (a 27\% decrease) the odds of indicating a higher level of achievement (Table 5). 
Table 5 - Model estimates

\begin{tabular}{|c|c|c|c|c|}
\hline & Estimate & $\begin{array}{c}\text { Std. } \\
\text { Error }\end{array}$ & p-value & $\operatorname{Exp}(B)$ \\
\hline \multicolumn{5}{|l|}{ Threshold: } \\
\hline [Weak to High achievement] & 2,53 & 1,514 & ,094 & \\
\hline [High to Full achievement] & 6,11 & 1,598 &, 000 & \\
\hline \multicolumn{5}{|l|}{ Location: } \\
\hline Dependence & 0,31 &, 108 & ,004 & 1,4 \\
\hline Trust & 0,53 &, 177 & ,003 & 1,7 \\
\hline Duration of the relationship & 0,11 & 053 & 032 & 1,1 \\
\hline Innovation: New to market & $-0,32$ &, 169 & 059 & 0,7 \\
\hline Innovation: New to firm & 0,18 &, 152 & 241 & 1,2 \\
\hline Innovation: Improvement & 0,20 &, 145 & , 176 & 1,2 \\
\hline Collaboration: Formal & 0,94 & 621 & ,131 & 2,6 \\
\hline \multicolumn{5}{|l|}{ Collaboration: Informal (reference) } \\
\hline M2: [access to] Knowledge, Yes & $-1,21$ & ,436 &, 005 & 0,3 \\
\hline \multicolumn{5}{|c|}{ M2: [Access to] Knowledge, No (reference) } \\
\hline M4: [Access to] Markets, Yes & $-0,35$ & ,408 & ,397 & 0,7 \\
\hline \multicolumn{5}{|l|}{ M4: [Access to] Markets, No (reference) } \\
\hline Type of Partner: STI & $-0,09$ & ,453 & 843 & 0,9 \\
\hline Type of Partner: Others & 0,42 & ,459 & ,357 & 1,5 \\
\hline \multicolumn{5}{|l|}{ Type of Partner: Firms (reference) } \\
\hline Dim: Micro & $-0,78$ &, 747 & 299 & 0,5 \\
\hline Dim: Small & $-0,57$ & ,695 & ,414 & 0,6 \\
\hline Dim: Medium & $-1,56$ & ,986 &, 115 & 0,2 \\
\hline \multicolumn{5}{|l|}{ Dim: Big (reference) } \\
\hline 1 Other RES & 0,53 & 1,057 & ,617 & 1,7 \\
\hline 2 Several RES & $-2,24$ & ,918 & ,015 & 0,1 \\
\hline 3 Wave & $-0,48$ &, 881 & ,588 & 0,6 \\
\hline 4 Systems engineering & $-0,85$ & ,625 & , 172 & 0,4 \\
\hline 5 Solar & $-0,57$ &, 576 & ,324 & 0,6 \\
\hline \multicolumn{5}{|l|}{6 Wind (reference) } \\
\hline $\begin{array}{l}\text { Activity: Own products or technologies } \\
\text { development }\end{array}$ & 0,46 &, 528 & ,381 & 1,6 \\
\hline $\begin{array}{l}\text { Activity: Third party integration or } \\
\text { commercialization }\end{array}$ & 0,12 & ,474 & ,808 & 1,1 \\
\hline \multicolumn{5}{|l|}{ Activity: Services (reference) } \\
\hline Frequency: occasionally & 0,29 &, 767 & ,707 & 1,3 \\
\hline Frequency: monthly & 0,88 & ,496 & ,075 & 2,4 \\
\hline Frequency: weekly & 0,41 & ,470 & ,383 & 1,5 \\
\hline Frequency: daily (reference) & & & & \\
\hline
\end{tabular}

DINÂMIA'CET - IUL, Centro de Estudos sobre a Mudança Socioeconómica e o Território 


\section{DISCUSSION AND CONCLUSIONS}

The results above displayed reveal that the characteristics of the partnerships prevail over the characteristics of the focal firms in explaining the perceived success of the partnerships. As to the former, the degree of trust, the degree of dependence vis-à-vis the partner and the duration of the relationship have a positive impact on the perceived level of achievement of the objectives, a proxy to the perceived success of the partnership. In addition, the monthly frequency of interaction has a positive effect when compared with the daily interaction, may be suggesting a mature relationship between partners. Finally, the objective 'Access to Knowledge' seems to influence negatively the level of achievement.

As to the characteristics of the firm, most of them are not significant, except the technological area (where 'Several RES' appear as negatively discriminated vis-à-vis the 'Wind' area) and the innovation strategy (where the introduction of 'New to the market products' seems to affect negatively the outcome).

We can detect a logic thread in the whole picture. Firstly, the level of achievement (proxy to success) depends mostly and almost exclusively on the attributes of the relationship established in each strategic partnership. Secondly, the structural characteristics of the firms are almost irrelevant, the exception being the technological area, and only when 'Several RES' is confronted with the 'Wind' area, taken as the reference. Thirdly, the results reveal that the adoption of a disruptive innovation strategy, the one that is associated with the introduction of new to the market products, technologies or services, is not conducive to more successful partnerships. This may be due to the fact that firms engaged in more disruptive innovation strategies establish partnerships which results are highly more uncertain. Fourthly, the negative influence of the objective 'Access to knowledge' on the outcome seems to corroborate the idea that the partnerships tend to be more successful when they are oriented to commercial objectives or other non-knowledge objectives, rather than to the creation of knowledge. We would like to stress the relevance that 'Trust' and 'Dependence' have in explaining the perceived success of the strategic partnership. This is certainly an interesting result. It is also interesting to find out that these elements supersede by far the importance of the firm's attributes. Taken together, these aspects suggest the existence of a dominant characteristic in the most successful partnerships: an orientation towards obtaining commercial results drawing on incremental innovation in existing technologies or technological solutions. This should correspond to the reality of the Portuguese sector specificity and maturity as we will explore in future research. 


\section{REFERENCES}

ANTONCIC, B. and Pordan, I. (2008). Alliances, corporate technological entrepreneurship and firm performance: Testing a model on manufacturing firms. Technovation, 28(5): 257-265.

AUDRETSCH, D.B. and Feldman, M.P. (2003). Small-firm strategic research partnerships: the case of biotechnology. Technology Analysis \& Strategic Management, 15 (2): 273-288.

AULAKH, P. S., Kotabe, M. and Sahay, A. (1996). Trust and performance in cross-border marketing partnerships: A behavioral approach. Journal of international business studies. 27(5): 1005-1032.

BAUM, J. A., Calabrese, T. and Silverman, B. S. (2000). Don't go it alone: Alliance network composition and startups' performance in Canadian biotechnology. Strategic Management Journal, 21(3): 267-294.

BERGEK, A., Jacobsson, S., Carlsson, B., Lindmark, S. and Rickne, A. (2008). Analyzing the functional dynamics of technological innovation systems: A scheme of analysis. Research Policy, 37(3): 407-429.

BROEKEL, T. and Boschma, R. (2012). Knowledge networks in the Dutch aviation industry: the proximity paradox, Journal of Economic Geography, 12(2): 409-433.

BROWN, J., Hendry, C. and Harborne, P. (2007). Developing Radical Technology for Sustainable Energy Markets: The Role of New Small Firms. International Small Business Journal, 25(6): 603629.

DAHL, M.S. and Pedersen, C.O.R. (2004). Knowledge flows through informal contacts in industrial clusters: myth or reality? Research Policy, 33 (10): 1673-1686.

DYER, J.H. and Singh, H. (1998). The relational view: Cooperative strategy and sources of interorganizational competitive advantage. Academy Of Management Review, 23(4): 660-679.

FONTES, M. and Sousa, C. (2015). Types of proximity in knowledge access by science-based start-ups, European Journal of Innovation Management (forthcoming).

FONTES, M., Sousa, C. and Pimenta, S. (2012). The commercialisation of emerging energy technologies: the strategic alliances of high-technology entrepreneurial firms, DINAMIA'CET Working Paper, WP n. ${ }^{\circ}$ 2012/05.

DINÂMIA'CET - IUL, Centro de Estudos sobre a Mudança Socioeconómica e o Território

ISCTE-IUL - Av. das Forças Armadas, 1649-026 Lisboa, PORTUGAL

Tel. 210464031 - Extensão 293100 E-mail: dinamia@iscte.pt http://dinamiacet.iscte-iul.pt/ 
FORD, D.P. (2004). Trust and knowledge management: the seeds of success. In Handbook on Knowledge Management 1 (pp. 553-575). Springer Berlin Heidelberg.

GILSING, V.A., Lemmens, C.E.A. and Duysters, G. (2007). Strategic alliance networks and innovation: A deterministic and voluntaristic view combined. Technology Analysis \& Strategic Management, 19 (2): 227-249.

GRANOVETTER, M. (1973). The strength of weak ties. American Journal of Sociology, 78(6): 1360-1380.

GRANOVETTER, M. (1982). The strength of weak ties: a network theory revisited, in Marsden, P. and Lin, N. (Eds.): Social Structure and Networks Analysis, Sage, Beverly Hills.

GRIN, J., Rotmans, J. and Schot, J. (2011). On patterns and agency in transition dynamics: Some key insights from the KSI programme, Environmental innovation and societal transitions, 1(1): 7681.

GULATI, R. (1995). Does familiarity bredd trust? The implications of repeated ties for contractual choice in alliances. Academy of Management Journal, 38(1):85-112.

HAGEDOORN, J. and Schakenraad, J. (1994). The effect of strategic technology alliances on company performance. Strategic Management Journal, 15 (4): 291-309.

HEKKERT, M.P., Negro, S.O. (2009). Functions of innovation systems as a framework to understand sustainable technological change: Empirical evidence for earlier claims. Technological Forecasting and Social Change, 76 (4): 584-594.

KEMP, R., Schot, J. and Hoogma, R. (1998). Regime shifts to sustainability through processes of niche formation: The approach of strategic niche management. Technology Analysis \& Strategic Management, 10(2), 175-198.

LAVIE, D. (2007). Alliance portfolios and firm performance: A study of value creation and appropriation in the U.S. software industry. Strategic Management Journal, 28(12): 1187-1212.

KACHRA, A. and White, R.E. (2008). Know-how transfer: The role of social, economic/ competitive, and firm boundary factors. Strategic Management Journal, 29 (4): 425-445.

KREINER, K. and Schultz, M. (1993). Informal collaboration in R\&D: the formation of networks across organizations. Organization Studies, 14(2): 189-209. 
LERNER, J. and Merges, R.P. (1998). The control of technology alliances: an empirical analysis of the biotechnology industry. Journal of Industrial Economics, 46(2): 125-156.

MCPHERSON, M., Smith-Lovin, L. and Cook, J.M. (2001). Birds of a feather: homophily in social networks. Annual Review of Sociology, 27: 415-44.

MOENSTED, M. (2007). Strategic networking in small high tech firms. International Entrepreneurship and Management Journal , 3 (1): 15-27.

MOHR, J. and Spekman, R. (1994). Characteristics of partnership success: partnership attributes, communication behavior, and conflict resolution techniques. Strategic Management Journal, 15(2): 135-152.

NORUŠIS, M.J. (2012). IBM SPSS Statistics 19 Advanced Statistical Procedures Companion, Prentice-Hall.

PERKMAN, M., Neely, A. and Walsh, K. (2011). How should firms evaluate success in university-industry alliances? A performance measurement system. $R \& D$ Management, 41(2): 202216.

POLITIS, J.D. (2003). The connection between trust and knowledge management: what are its implications for team performance. Journal of Knowledge Management, 7 (5): 55-66.

POWELL, W. and Grodal, S. (2005). Networks of innovators, in J. Fagerberg, D.C. Mowery and R.R. Nelson (eds.), The Oxford Handbook of Innovation, Oxford: Oxford University Press.

POWELL, W., Koput, K. and Smith-Doerr, L. (1996). Interorganizational collaboration and the locus of innovation: networks of learning in biotechnology. Administrative Science Quarterly 41(1): 116-145.

REN21 (2011). Renewables 2011 Global Status Report, Renewable Energy Policy Network for the 21st Century, Paris: REN Secretariat.

REUER, J.J., Zollo, M. and Singh, H. (2002). Post-formation dynamics in strategic alliances. Strategic Management Journal, 23(2): 135-151.

ROTHAERMEL, F.T. (2001). Complementary assets, strategic alliances, and the incumbent's advantage: an empirical study of industry and firm effects in the biopharmaceutical industry, Research Policy, 30(8): 1235-1251.

DINÂMIA'CET - IUL, Centro de Estudos sobre a Mudança Socioeconómica e o Território 
SALAVISA, I., Sousa, C. and Fontes, M. (2012). Topologies of innovation networks in knowledge-intensive sectors: Sectoral differences in the access to knowledge and complementary assets through formal and informal ties, Technovation, 32(6): 380-399.

SHANE, S. and Stuart, T. (2002). Organizational endowments and the performance, Management Science, 48(1): 154-70.

STUART, T.E., Ozdemir, S.Z. and Ding, W.W. (2007). Vertical alliance networks: the case of university-biotechnology-pharmaceutical alliance chains, Research Policy, 36(4): 477-498.

TEECE, D.J. (1986). Profiting from technological innovation: implications for integration, collaboration, licensing and public policy. Research Policy, 15(6): 285-305.

WANG, R. and Rubenstein-Montano, B. (2003). 'The value of trust in knowledge sharing', in Coakes, E. (Ed.): Knowledge Management: Current Issues and Challenges, IRM Press, Hershey, PA, pp.116-130.

ZHAO, L. and Aram, J. (1995). Networking and growth of young technology-intensive ventures in China. Journal of Business Venturing, 10(5): 349-370. 